\title{
Are Foreign Banks Always the Best? Comparison of State-Owned, Private and Foreign Banks in India*
}

March 31, 2006

\author{
Rudra Sensarma ${ }^{1}$ \\ Indian Institute of Management \\ Lucknow, India
}

\begin{abstract}
Researchers have used different approaches and techniques to measure bank performance but most of these studies have been restricted to developed economies. Among the few papers that exist for developing economies, either efficiency or productivity of banks have been estimated based on which inferences about the banking industry have been made. In this paper we estimate efficiency of Indian banks and then estimate a measure of productivity that includes an efficiency term. Following this comprehensive measure, we find that banks have improved their performance during the period 1986 to 2000 in terms of both efficiency and productivity. Surprisingly, foreign banks have been the worst performers throughout the period as compared with state owned and private domestic banks.
\end{abstract}

Keywords: banking, efficiency, productivity, cost, frontier.

JEL classification: D21, G21, G28, L33.

${ }^{*}$ Acknowledgements: I would like to thank an anonymous referee for helpful comments that have led to substantial improvements in the paper. I am deeply indebted to Subrata Sarkar for his help and suggestions. I also thank, for useful comments, Padmini Dasgupta and seminar participants at Indian Statistical Institute, Kolkata where an earlier version of this paper was presented.The remaining errors, if any, are my responsibility.

${ }^{1}$ Address for Correspondence: Rudra Sensarma, Indian Institute of Management, Prabandh Nagar, Off Sitapur Road, Lucknow-226013, Uttar Pradesh, India. Telephone: +91-522-2736646, Fax: +91-522-2734025, E-mail: rsensarma@gmail.com 


\section{Introduction}

Recent years have seen an explosion in research on bank performance across the globe. ${ }^{2}$ While researchers have used a variety of approaches to measure bank performance, most of the studies have been restricted to developed economies. Among the few papers that exist for developing economies, the two common approaches to measuring performance are to estimate either efficiency or productivity of banks based on which inferences about the banking industry are made. The same is true for papers on Indian banking. In other words, these papers have either estimated efficiency (using a frontier technique) or separately estimated productivity (ignoring the efficiency factor). In this paper, we estimate efficiency of Indian banks and then, following Kumbhakar and Lovell (2000), estimate a measure of productivity that includes the efficiency term. The results from such an analysis are quite interesting. We find that both efficiency as well as productivity of foreign banks have been consistently lower than those of domestic banks. Among the domestic banks, the public banks benefited the most from the deregulation process and had higher efficiency than private banks. In terms of productivity, private banks appear to have performed better, driven mostly by technical progress.

Existing research on the comparative performance of foreign banks and domestic banks show conflicting conclusions. It has been found that foreign banks are more profitable than domestic banks in developed countries while it is the other way round in developing countries (Claessens, Demirguc-Kunt and Huizinga, 2000). To cite some country-specific studies, for the U.S. it has been observed that foreign banks are less efficient than domestic banks (Hasan and Hunter, 1996). But other studies have found that foreign banks are nearly as efficient as domestic banks in developed countries other than the U.S. (Vennet, 1996; Hasan and LozanoVivas, 1998). For the transition economies of Central and Eastern Europe, it has been found that foreign banks were less efficient than domestically owned private banks and state-owned banks (Yildirim and Philippatos, 2002). In the case of Latin America, some studies have found that foreign banks were more productive than domestic banks (Barajas, Steiner and Salazar, 2000) while some others reported little difference between the performance of the foreign and domestic banks (Crystal, Dages and Goldberg, 2002).

In this paper we try to compare the performance of foreign banks operating in India with the domestic banks. India provides a unique case study whereby banking industry is charac-

\footnotetext{
${ }^{2}$ See Alam (2001) and Berger and Mester (2003) for discussions of recent literature.
} 
terized by a mixed ownership structure and the deregulation of the industry in the nineties had paved the way for a level playing field between the various ownership groups. Existing studies on bank performance in India appear to be insufficient in comprehensively comparing the performance of foreign banks with domestic banks. Kumbhakar and Sarkar (2003a) estimated Total Factor Productivity (TFP) growth and its components using a generalized shadow cost function approach for public and private banks from 1986 to 1997. This paper did not allow for inefficiency effects in the analysis. On the other hand, Kumbhakar and Sarkar (2003b) and Shanmugam and Das (2004) estimated bank efficiency using various stochastic frontiers but did not study productivity. It may be mentioned that the present paper uses a large period of data (viz. 1985 to 2000) to assess the relative performance of different bank groups in India. The data period allows us to also study the impact of deregulation on bank performance. Essentially, the empirical estimation of the paper proceeds in two steps. The first step deals with estimation of efficiency using stochastic frontier analysis. In the next step, measures of productivity are computed based on the stochastic frontier estimates.

The rest of the paper is organized as follows. Section 2 provides a brief overview of the banking industry in India. Section 3 discusses the econometric methodology we employ. Section 4 introduces the data used in the paper and formalizes the econometric specification. Section 5 and Section 6 are devoted to discussions of the results from the analysis of efficiency and productivity, respectively. Finally, Section 7 summarizes and concludes.

\section{Institutional Structure and Recent Changes in Indian Bank- ing}

The importance of banking in the Indian economy can be gauged from the fact that aggregate deposits stood at $49 \%$ of GDP in 2002 and bank credit to the government and commercial sector stood at $26 \%$ and $33 \%$ of GDP respectively in 2002 (Reserve Bank of India, 2005). The banking industry in India is characterized by the coexistence of state-owned or public sector banks, domestic private incumbents (or private banks), foreign banks and domestic private entrants (or new private banks). Historically, the industry was dominated by the public sector

banks while the activities of the private sector (both domestic and foreign) were severely controlled by India's Central Bank, the Reserve Bank of India. However falling profitability 
and inefficiency in the banking system precipitated the first set of banking sector reforms in 1992 that facilitated entry deregulation, branch de-licensing, deregulation of interest rates, and operational freedom for public sector banks. Consequent to these reforms, 9 new private banks started operations in the mid-nineties.

A level playing field was created by subjecting all bank groups to the same prudential norms, such as Cash Reserve Ratio (CRR) and Statutory Liquidity Ration (SLR), while also introducing capital adequacy norms and income recognition and provisioning norms. In the backdrop of the South-East Asian Crisis and the Basel Committee recommendations, the 'second generation reforms' of the late nineties imposed stricter capital adequacy and Non-Performing Assets (NPAs) norms, market risk on government securities, and introduced Assets-Liabilities management and Risk management guidelines.Thus the banking reforms, initiated since 1992 were intended to impart enhanced efficiency, productivity and profitability into the system. Even in this level playing field, the industry is still dominated by a few large banks and entry is still closely monitored by the regulator. This has encouraged strategic competition among banks and the market structure is closer to that of oligopoly. Hence, it is in this backdrop that we attempt to assess the relative performance of the public sector banks with the domestic private and the foreign banks.

\section{$3 \quad$ Econometric Methodology}

The disadvantage of using regression models in studying bank performance (as in Kumbhakar and Sarkar, 2003a) is that such models assume that all banks are equally efficient which is quite a strong restriction. It is widely accepted that large variations in banking data necessitates the application of frontier analysis. In this paper we employ the parametric method of stochastic frontier analysis (SFA) because of its ability to capture error in the data that may arise out of luck, data problems, or other measurement errors. ${ }^{3}$

SFA was developed independently by Aigner, Lovell and Schmidt (1977) and Meeusen and van den Broeck (1977). Since then, the original specification has been modified and extended in a number of ways. In this paper we will be using the Battese and Coelli (1995) methodology of stochastic frontier analysis which is popular in the literature due to several advantages

\footnotetext{
${ }^{3}$ The other popular frontier technique is the Data Envelopment Analysis which is a non-parametric method that does not allow for any random error.
} 
that it offers compared to traditional methodologies. It allows simultaneous estimation of the frontier function and the inefficiency function in a single maximum likelihood procedure which avoids the theoretical problems of the traditional two-step approaches (Battese and Coelli, 1995). Moreover, it is easily amenable to analysis of panel data and allows for timevarying inefficiency. As regards the specification of the frontier, banking being a multi-product industry, we take recourse to the cost function for estimating efficiency. The Battese and Coelli (1995) model for a cost frontier is briefly outlined as follows. Assuming that a producer's objective is to minimize cost, the cost frontier based on panel data can be represented as:

$$
C_{i t}=f\left(Y_{i t}, W_{i t}\right)+U_{i t}+V_{i t}
$$

where $i$ indexes banks and $t$ indexes time. As for the variables, $C$ is cost, $Y$ is the output vector and $W$ is a vector of factor prices (all variables measured in logs). The random error, $V_{i t} \sim$ iid $N\left(0, \sigma_{V}^{2}\right)$, and the inefficiency factor, $U_{i t} \sim$ non-negative truncation of independently distributed $N\left(\mu_{i t}, \sigma_{U}^{2}\right)$, where, $\mu_{i t}=Z_{i t} \delta .{ }^{4}$ The inefficiency model is thus specified as:

$$
U_{i t}=Z_{i t} \delta+\epsilon_{i t}
$$

where $Z_{i t}$ is an $1 x p$ vector of variables which may influence the inefficiency of a firm and $\delta$ is a px1 vector of parameters to be estimated. The $i^{\text {th }}$ bank's cost efficiency relative to the cost frontier is defined as, $C E_{i t}=\exp \left(-U_{i t}\right)$. The parameterization from Battese and Corra (1977) is used, replacing $\sigma_{V}^{2}$ and $\sigma_{U}^{2}$ with $\sigma_{S}^{2}=\sigma_{V}^{2}+\sigma_{U}^{2}$ and $\gamma=\sigma_{U}^{2} / \sigma_{S}{ }^{2}$. The parameters are estimated by the Maximum Likelihood (ML) approach. The log-likelihood function of this model is given in Battese and Coelli (1993).

\section{Data and Econometric Specification}

The first step in modeling bank behavior is to decide whether deposits form part of output or input of a bank. We follow the value added approach (Berger and Humphrey, 1992; Grifell-

\footnotetext{
${ }^{4}$ Because we are pooling banks with different sizes, the data may be characterized by heteroskedasticity. This may lead to biased estimates in a stochastic frontier model where one part of the error term is distributed asymmetrically (Caudill, Ford and Gropper, 1995; Hadri, 1999). Christopoulos and Tsionas (2001) have discussed this issue specifically in the context of banking. According to Wang (2003), the heteroskedasticity of $U$ can be modeled through a non-constant $\mu$ or a non-constant $\sigma_{U}{ }^{2}$ or both. The approach of Battese and Coelli (1995) is to make $\mu$ observation specific and we follow this since the other approaches lead to loss of too many degrees of freedom.
} 
Tatje and Lovell, 1996; Berg et al., 1993) that treats deposits and loans as output. ${ }^{5}$ Thus, our output vector consists of value of fixed deposits (FD), saving deposits (SD), current deposits (CD), investments (INV) and loans and advances (ADV). Apart from these, we also include the number of branches (B) as an output variable. Branches can proxy for the quality of services (Berg et al., 1993) and therefore ignoring branches amounts to omitting a costly service that provides transactions convenience to customers (Grifell-Tatje and Lovell, 1996). Number of branches also proxies for the size of bank transactions. This is important since the deposit and loan outputs of a bank should be ideally measured in terms of number of deposit and loan accounts produced by a bank rather than their value (Grifell-Tatje and Lovell, 1996). Given the unavailability of the number of accounts data in India, while we employ the value of deposits and loans of each bank as output, it might be appropriate to use the number of branches as an imperfect control for the size of transactions. Labor $(L)$ and Capital $(K)$ are the two variable inputs. The dependent variable is total operating cost $(C)$, which is the sum of labor and capital costs (it does not include interest expended).

Price of labor $\left(w_{L}\right)$ is obtained by dividing total establishment expenses by total number of employees. Price of capital $\left(w_{K}\right)$ is obtained by dividing the total capital expenditure by total fixed assets. All nominal variables are converted to real by measuring them at 1993-94 prices. The data is taken from various issues of Financial Analysis of Banks and Performance Highlights of Banks published by the Indian Banks' Association. We use data on 27 public sector banks (public banks, henceforth), 25 domestic private sector banks (private banks, henceforth), 22 foreign banks, and 9 new domestic private sector banks (new private banks, henceforth) that started operating after deregulation. New private banks are the only entrants in this study and their data is available from $1996 .{ }^{6}$ In selecting the old private banks and foreign banks, we used data availability as the criterion of inclusion in our sample. 15 years of data is taken from the year 1986 to 2000.

Note that we differ from the existing cost-based studies in Indian banking (e.g. Kumbhakar and Sarkar, 2003a; Kumbhakar and Sarkar, 2003b; Shanmugam and Das, 2004) in several ways. First, we are including both foreign and new private (entrants) banks as separate

\footnotetext{
${ }^{5}$ Indeed most studies on Indian banks have used this approach (see Das, 1997; Kumbhakar and Sarkar, 2003a; Kumbhakar and Sarkar, 2003b). The value added approach also appears to be intuitively more appealing for Indian banking where deposit mobilization is one of main the objectives of banks. Moreover, considering deposits as output takes into account the quality of services provided by a bank.

${ }^{6}$ In our set of 83 banks, none of the foreign banks that entered the industry after entry deregulation could be included because of considerations of data availability.
} 
groups in the analysis. This allows us to compare the performance of foreign banks and domestic entrants with the domestic incumbents. Second, we look at the role of size in determining efficiency. Third, we consider each category of deposit as a separate element in the output vector since they are inherently different in characteristics and banks' strategy regarding each category might be different. Fourth, our estimates of TFP growth include a component for efficiency growth obtained from the SFA, which has not been considered by any of the existing studies.

We adopt the translog (transcendental logarithm) form which is a second order approximation of any unknown function as our specification of the frontier in expression (1). The translog function in our case takes the following form: $\ln C_{i t}=a_{0}+\sum_{m} a_{m} \ln y_{m i t}+\sum_{j} b_{j} \ln w_{j i t}+b_{t} t+$

$$
\begin{aligned}
& 0.5 \sum_{m} \sum_{l} a_{m l} \ln y_{m i t} \ln y_{l i t}+0.5 \sum_{j} \sum_{k} b_{j k} \ln w_{j i t} \ln w_{k i t}+0.5 b_{t t} t^{2}+ \\
& \sum_{m} \sum_{j} a_{m j} \ln y_{m i t} \ln w_{j i t}+\sum_{m} a_{m t} \ln y_{m i t} t+\sum_{j} b_{j t} \ln w_{j i t} t+u_{i t}+v_{i t}
\end{aligned}
$$

Next we impose certain theoretically desirable properties. We apply the usual symmetry restrictions, that follow from Young's theorem, $a_{m l}=a_{l m}$ and $b_{j k}=b_{k j}$. To ensure linear homogeneity in $w$, the following restrictions are imposed, $\sum_{j} b_{j}=1, \sum_{j} b_{j k}=0 \forall k$, $\sum_{j} a_{m j}=0 \forall m, \sum_{j} b_{j t}=0$. Cost and input prices are normalized by the price of capital before taking logarithms to impose linear input price homogeneity.

Next, to model the inefficiency term, we hypothesize that the determinants of bank inefficiency are deregulation, size and nature of ownership. We also include labour and capital (in logarithm terms) as explanatory variables for inefficiency to allow for non-neutral specification (Huang and Liu, 1994). Hence we specify the inefficiency equation, once again in translog form, as follows: $U_{i t}=\delta_{0}+\sum_{k} \delta_{i} Z_{k i t}+0.5 \sum_{k} \sum_{r} \delta_{k r} Z_{k i t} Z_{r i t}+\epsilon_{i t}$

The vector $Z_{i t}$ includes the following variables, $Z_{i t}^{\prime}=$ (T, DEREG, SIZE, PUB, PVT, NEWPVT, $L, K$ ), where the square of the dummy variables are excluded to avoid singularity of the regressor matrix. $T$ is year which represents change in inefficiency over time. DEREG is a deregulation dummy that takes the value one for years 1993 and above, and zero otherwise. ${ }^{7}$ Deregulation is expected to have reduced inefficiency in the banking sector. SIZE is taken to be log of total assets (i.e. sum of INV and ADV). The coefficient of SIZE would indicate the

\footnotetext{
${ }^{7}$ The year 1993 was selected as the deregulation year because it yielded the maximum value of likelihood function compared to the other years and also the plot of inefficiencies without any deregulation dummy showed the sharpest kink at 1993. This is expected because implementation of the recommendations of the first Narasimham Committee, that triggered off banking reforms in India, started in January 1992 (Kumbhakar and Sarkar, 2003b).
} 
effect of bank size on inefficiency.

PUB, PVT and NEWPVT are ownership dummies that take value one if the bank belongs to the public sector, private sector and new private sector respectively. The only other sector is foreign, which becomes the base for interpreting the ownership dummies. As discussed earlier, inefficiency is expected to vary across ownership groups because of the difference in governance structures. Interactive terms among the above variables are expected to indicate how each explanatory factor may be affecting inefficiency through interaction with another.

\section{Empirical Findings on Efficiency}

We estimate the cost frontier twice, once without including any bank group dummies in the frontier and next with group dummies. The former (which we will refer to as Model 1) provides a common frontier for the banking industry relative to which the inefficiencies are estimated whereas the latter (which we will refer to as Model 2) makes the frontier specific to environmental conditions in each bank group. The results of the estimation for the common frontier and the group-specific frontier are summarized in Tables 1 and 2 respectively. Since the main focus of the analysis is on inefficiency and its determinants, we do not discuss the estimated coefficients of the cost frontier in details. However we note that while the coefficients of fixed deposits and branches are positive as expected, it is not so for the output variables. But these signs themselves are not of much concern, since the theoretical requirement is that the cost elasticity of output should be positive, which we do obtain (with a few exceptions) when we consider all the interaction terms and compute the corresponding elasticities.

(Tables 1 and 2 here)

Before we discuss the estimated parameters of the inefficiency function and present the inefficiency estimates we ought to verify statistically whether there is any need to use the stochastic frontier model framework and whether bank-specific inefficiency effects are at all present in the cost function of Indian banking. This can be done by first performing a composite test of $\gamma=\delta_{0}=\ldots=\delta_{13}=0$. The test uses a generalized likelihood ratio (LR henceforth) which follows a mixed chi-squared distribution (Coelli and Battese, 1996). A generalized LR test is required since $\gamma$ can not take negative values and hence the test must

be performed as a one-sided test. Moreover, the LR test statistic does not have a chi-square distribution because the restriction defines a point on the boundary of the parameter space. 
In this case the likelihood ratio statistic follows a mixed chi-square distribution with degrees of freedom equal to the number of parameters.

The generalized likelihood ratio test rejected the above hypothesis (LR test statistic of the one-sided error is 692.29 for Model 1 and is 711.17 for Model 2, both of which are greater than the appropriate mixed-Chi square statistic available in Table 1 of Kodde and Palm, 1986). Hence the simple average response function estimation is not adequate and a stochastic frontier estimation is necessary. We also test whether the inefficiency effects have a traditional half-normal distribution with zero mean or not. This can be done by testing for $\delta_{0}=\ldots=\delta_{13}=0$. A generalized LR test rejected the above hypothesis (LR test statistic is 690.67 for Model 1 and 692.90 for Model 2, both of which are greater than the appropriate mixed-Chi square statistic available in Table 1 of Kodde and Palm, 1986). Hence our tests suggest that indeed bank specific inefficiency effects are present and that such inefficiencies are better modeled within a stochastic frontier framework.

Moving to the behavior of inefficiency, from Tables 1 and 2 we observe the role of determinants of inefficiency from the last three columns of the tables. The impact of each variable of the $\mathrm{Z}$ vector on inefficiency can be understood by collecting and computing all terms in $\frac{\partial E\left(U_{i t}\right)}{\partial Z_{k i t}}$ from the inefficiency equation. The coefficients of most of the terms containing $\mathrm{T}$ in the inefficiency model are negative. In fact, collecting all relevant terms it has been observed that the impact of $\mathrm{T}$ on inefficiency is negative in both models 1 and 2 , which suggests that during the sample period, cost efficiency increased over time on an average for the industry. However, deregulation led to an increase in cost inefficiency. ${ }^{8}$ This is indicated by a positive and significant coefficient of DEREG in a model with only $\mathrm{T}$ and DEREG*T as regressors in the inefficiency equation. This suggests that deregulation led to a fall in cost efficiency, although there was a temporal increase in cost efficiency during the entire period.

The role of ownership in determining cost inefficiency is provided by the group dummies. We observe that most of the terms containing the public, private and new private dummies are significant in both models 1 and 2, indicating that ownership is indeed a significant determinant of inefficiency. The relative performance of the bank groups would be analyzed later by presenting figures of average cost efficiency across groups. The next question we turn to is the role of size in cost inefficiency. In other words, are big banks more efficient or less

\footnotetext{
${ }^{8}$ This result is consistent with Kumbhakar and Sarkar (2003b).
} 
efficient than small banks? Moreover, since public banks are on an average bigger than the other bank groups, it is natural to ask whether it is the effect of size that tends to show up through the public bank dummy. Collecting all terms containing SIZE and computing its impact on inefficiency revealed a positive relationship in both models, thereby implying that size adversely affects cost efficiency.

Next we discuss the behavior of cost efficiency in both models. From the bank-wise estimates of efficiency, we computed the group-wise efficiency estimates for each year by taking a simple mean over the constituent banks of each group. ${ }^{9}$ These mean efficiencies are reported in Table 3 and are presented graphically in Figure 1. We observe for Model 1 that in most of the years, private banks appear to have performed better in terms of cost efficiency than the public, new private and foreign banks in that order. Although the immediate impact of deregulation was to reduce cost efficiency, public banks were gradually able to take advantage of the deregulation process better than the private banks and outperformed them in the later years. Compared to the other groups, new private banks appear to have achieved a rapid rise in cost efficiency. This may have happened due to their late entry into the industry because of which they had the advantage of not carrying any baggage from the past, as was the case with the other groups. Therefore the new private banks may have successfully managed their business at lower operating costs than the other groups. The striking part of the results is that foreign banks appeared to have the lowest cost efficiency. This is contrary to popular perception in India and we try to explain this result later. However in Model 2 we observe that public banks have higher cost efficiency than private banks throughout the sample period.Foreign and new private banks come next in the order.

(Table 3 and Figure 1 here)

The above results can be interpreted as follows. First, the decline of cost inefficiency over the entire sample period is consistent with Kumbhakar and Sarkar (2003b) who found that although cost inefficiency declined over time, the rate of decline slowed down subsequent to deregulation. It is expected that over time, with increased competitive pressure and entry of new banks, intermediation costs will come down and thereby cost efficiency of the banking sector will rise. Banks, in general, have been able to contain operating costs, and have therefore moved towards the best banks (that comprise the frontier) over the entire time

\footnotetext{
${ }^{9}$ Weighted means did not change the results qualitatively.
} 
period. However the immediate impact of deregulation was to increase cost inefficiency. Deregulation brought about substantial changes in technology and business practices, that is expected to shift the cost frontier inwards. However individual banks may have been slow to respond and reorient their strategies to the changing circumstances. But over time they are expected to catch up with the 'best' banks comprising the frontier. Thus, although efficiency decreased around the time of deregulation, over time and overall, there has been a rise.

Second, private banks are more cost efficient than public banks in the pre-deregulation period when compared in a common frontier. In this respect, the pre-deregulation situation is consistent with the property rights hypothesis and public choice theory. ${ }^{10}$ However public banks benefited more from deregulation and outperformed the private banks subsequent to deregulation in terms of their cost efficiency. On the other hand when compared to groupspecific frontiers, private banks appeared to be less cost efficient than public banks even in the pre-deregulation period. In other words while there were private banks lying close to the industry frontier prior to deregulation, yet most of the public banks were closer to the 'best' banks in their own group. However subsequent to deregulation, not only did public banks continue to be close to their own frontier, there were more public banks comprising the industry frontier than private banks. Thus overall, private banks appear to have been less cost efficient and more so in the post-deregulation period. This could be because private banks took the lead in investing in new revenue generating practices which led to a lot of additional costs. These were in the form of computerization of branches, setting up of Advanced Ledger Posting Machine (ALPM) branches, computer training of employees, upgradation of technology etc. Thus, while the private banks might have made these costly investments with an eye on earning higher revenues, they appear to have lost out in terms of cost efficiency. Provision of better quality of output may lead to enhanced revenues for banks even while they take a hit in terms of cost efficiency. Berger and Mester (2003) refer to this as the 'increasing quality hypothesis'.

Foreign banks were the worst performers in terms of cost efficiency in both models. The reasons for this could be that foreign banks incur huge expenditure in paying high salaries to employees. A survey conducted on 62 banks by the Reserve Bank of India found that as on March 31, 2002, staff expenses per employee in million Indian Rupees was the highest for

\footnotetext{
${ }^{10}$ Both these theories opine that private entities are more efficient that public entities due to weakly defined property rights and $\mathrm{X}$-inefficiencies present in the latter.
} 
foreign banks at 9.16 , followed by new private banks at 3.04 , public banks at 2.53 and private banks at 2.13 (Reserve Bank of India, 2002). ${ }^{11}$ In fact an overwhelming proportion of employees in foreign banks are highly paid officers as compared with domestic banks which employ proportionately more clerks and subordinates. Foreign banks also incur huge expenditure on costly real estate being mostly based in urban and metropolitan areas. Moreover, the public and private banks have a historical advantage of having established business structures and infrastructure in India which most of the new foreign banks do not.

Further, the use of technology is much more in the case of foreign banks which may lead to huge costs. This is evidenced by the above mentioned survey which showed that foreign banks were ahead of the public and private banks in terms of Information Technology use. Domestic banks have a large part of their portfolio as committed lending in the priority sector while foreign banks incur a lot of expenditure in trying to push retain loans in order to expand their asset portfolio. Another reason why foreign banks performed badly could be that foreign banks in India are really small fractions of their parent entities who operate globally. The foreign banks in India are branch offices of the parent bank, and not subsidiaries. Thus the parent entities may not put much emphasis on the performance of their few Indian branches. Moreover, the foreign banks operating in India are not listed in the Indian stock markets. Hence the market forces that usually cause private entitites to be more efficient than public entities may not be operating on foreign banks. ${ }^{12}$ However, while foreign banks did badly on the cost front, they might actually have incurred new costs in order to hunt for newer sources of revenue ('increasing quality hypothesis'). In fact, both foreign and private banks tried to garner newer sources of revenue, for which they undertook additional expenditure thereby taking them away from the cost frontier.

Thus, subsequent to deregulation, cost efficiency of public banks has been higher relative to other bank groups. With the introduction of sufficient deregulation, public banks could improve their performance in terms of cost efficiency and outperform their private counterparts. On the other hand, as mentioned already, the improvement in cost efficiency of public banks vis-a-vis private banks could also have happened because the private banks incurred

\footnotetext{
${ }^{11}$ The exchange rate was 48.8 Rupees to a Dollar at end-year 2002.

${ }^{12}$ While it may be true that the scrips of only a few private banks are actively traded in the stock market, the process of listing itself requires the disclosure of certain parameters as mandated by Securities and Exchange Board of India (SEBI), which is the capital market regulator. These disclosure norms may lead to market pressure on the listed banks to improve their performance.
} 
a lot of costs in attempting to provide superior quality of services with the expectation of higher revenues. Thus, the role of competition appears to be strong in terms of affecting performance of banks in terms of cost efficiency.

Lastly, bigger banks were seen to be less cost efficient. This indicates that it might be more difficult to manage costs in bigger banks, which gets reflected in lower cost efficiency. This result has been reported earlier in the literature. For example, Christopoulos, Lolos and Tsionas (2002) found that in Greece, larger banks are less cost efficient than their smaller counterparts. They attribute it to the fact that larger banks tend to have inefficient management, low staff motivation and strict labor relations. Moreover, bigger banks have a greater burden of the cost of maintaining an extended branch network which caters to deposit mobilization but does not contribute to selling priced products. This may be true for Indian banks as well.

So far we have estimated cost efficiency of Indian banks. This is only one measure of bank performance and we need to compute productivity to complete the picture. In fact a low (high) value of one of these two measures does not necessarily imply a low (high) value of the other. Productivity consists of scale effects and technical change effects, in addition to efficiency growth. Hence, a bank with low cost efficiency could be reaping scale economies so as to have a high productivity growth. Alternatively, it could also have higher productivity growth through a shift in the frontier (technical change) due to implementation of better technology. Thus a study of performance would remain incomplete without an analysis of productivity growth. We turn to these issues in the following section.

\section{Productivity Analysis}

TFP of any firm can be intuitively understood as a measure of output produced relative to input usage. Efficiency change, as estimated in the previous section, can be viewed as one of the components of a broader measure of TFP growth. According to Kumbhakar and Lovell (2000), until very recently, econometric models of productivity growth had ignored the role of efficiency growth. Productivity growth was supposed to consist of shifts in production technology i.e. technical change, and also the biases of technical change and the structure of the technology i.e. scale economies. Kumbhakar and Lovell (2000) give a measure of TFP based on the cost frontier consisting of the above two components as well as efficiency growth, 
which we discuss below.

The Divisia index of TFP growth for multiple outputs can be written as: ${ }^{13}$

$$
\begin{array}{r}
T \dot{F} P=\dot{Y}-\dot{X} \\
=\sum_{m} R_{m} \dot{y_{m}}-\sum_{m} S_{m} \dot{x_{m}}
\end{array}
$$

where $R_{m}=p_{m} y_{m} / \sum_{m} p_{m} y_{m}$ is the revenue share of output $y_{m}, p_{m}$ is the price of output $y_{m}$ and $S_{m}$ is the cost share of input $x_{m}$.

Kumbhakar and Lovell (2000) considered the following deterministic cost frontier:

$$
\ln E=\ln C(Y, W, t)+U
$$

where, $E=W X$ is total expenditure, $X=\left(x_{1}, \ldots, x_{N}\right) \geq 0$ is the input vector, $W>0$ is the input price vector, $Y=\left(y_{1}, \ldots, y_{M}\right) \geq 0$ is the output vector, $t$ is a time trend that serves as a proxy for technical change, $C(Y, W, t)$ is the deterministic kernel of a stochastic cost frontier, $U$ is the technical inefficiency term. Totally differentiating equation (4), solving for $\dot{Y}$, substituting it in (3) and some algebraic manipulation yields an estimable expression for TFP growth:

$$
T \dot{F} P=-\dot{C}(Y, W, t)+[1-\epsilon(Y, W, t)] \dot{Y}-\frac{\partial U}{\partial t}
$$

where $\epsilon(Y, W, t)=\sum_{m} \epsilon_{m}(Y, W, t), \epsilon_{m}(Y, W, t)$ is cost elasticity of the $m^{t h}$ output, and $\dot{Y}=\sum_{m}\left[\frac{\epsilon_{m}(Y, W, t)}{\epsilon(Y, W, t)}\right]$ is a measure of aggregate output growth. Expression (5) provides a decomposition of TFP growth into a technical change component (say, $T \dot{F} P_{1}$ ), a scale effect component (say, $T \dot{F} P_{2}$ ) and an efficiency growth component (say, $T \dot{F} P_{3}$ ). Thus we have TFP growth as a sum of three components as follows:

$$
T \dot{F} P=T \dot{F} P_{1}+T \dot{F} P_{2}+T \dot{F} P_{3}
$$

In this study, we construct indices of each component of TFP, i.e. $T F P_{i}(t)=T F P_{i}(t-$ 1) $\left[1+T \dot{F} P_{i}(t)\right]$ and it is set at 100 for the first year. The mean $T \dot{F} P_{i}$ are calculated for each bank group for each year. Based on these means, $T F P_{i}$ are computed for each bank group

\footnotetext{
${ }^{13}$ Note that the Tornqvist index is a discrete approximation of the continuous Divisia index.
} 
for each year. TFP is computed in a similar fashion. ${ }^{14}$ Once again we report our estimates based on both a common frontier (Model 1) and group-specific frontiers (Model 2). It also needs to be noted here that the TFP figures for new private banks are not strictly comparable with those of the other groups since the initial year for this group is 1996 at which their TFP is set to be 100 , whereas the initial year for all other groups is 1986 . The mean values for all bank groups are reported in Tables 4 and 5 for Model 1 and in Tables 6 and 7 for Model 2 .

(Tables 4, 5, 6 and 7 here)

The estimates of $T F P_{1}$ give the technical change component. Estimates from both models 1 and 2 reveal that there has been a technical improvement across the industry as far as costs are concerned. The exception is foreign banks for whom the index shows a decline. Thus, for the domestic banks there was a downward shift in the cost frontier. It is only expected that over the years and aided by deregulation, there would be significant improvements in technology, procedures and practices for domestic banks, which could shift the cost frontier inwards (Kumbhakar and Sarkar, 2003b). Moreover, in an economy moving from a regulated to a deregulated regime, competition is expected to drive down intermediation costs which would also get manifested as inwards shift of the cost frontier leading to improvement in the technical change component of TFP. A similar result was obtained by Chaffai (1997) for Tunisian banking whereby he found that deregulation had indeed led to technical progress.

There is also a clear hierarchy in the way bank groups have behaved. Private banks have performed the best, followed by public and foreign banks. Although the TFP levels of new private banks are not strictly comparable with the other groups, we can observe that there was technological improvement even for this group of banks. By reconstructing all the indices with the value for 1996 as 100 , we could incorporate comparable values of all groups with new private banks for the period 1996-2000. This showed that new private banks were second only to private banks in performance in this period. It may be mentioned that Kumbhakar and Sarkar (2003a) found no significant technological improvement in public or private banks. Their study however did not have a cost frontier, whereas our results show that the cost frontier has indeed shifted inwards which gets manifested as technical change.

Tables 4 to 7 also report the movement of mean $T F P_{2}$ which gives the scale effect compo-

\footnotetext{
${ }^{14}$ Since the initial value of the productivity indices are set at 100 for all groups, here we miss out the difference in their initial levels which we were able to analyze from the efficiency estimates. However, here the indices can suggest, based on the growth rates of each component of productivity, how the bank groups corrected or worsened their performance.
} 
nent. As discussed earlier, this component of TFP is based on the aggregate output growth and the elasticities. This component basically reflects the effect of returns to scale and output expansion on TFP growth. Our estimates for Model 1 show that all banks exhibit a stagnant or marginal decline in $T F P_{2}$ but in Model 2 the estimates for private, foreign and new private banks exhibit a rise. This result is similar to the recovery for private banks found by Kumbhakar and Sarkar (2003a) who state that "this is perhaps expected because the opportunity to realize potential scale economies was significantly enhanced in the post-deregulation period with the removal of various regulations that prohibited the expansion of private banks in the earlier years." Since the figures for new private banks are not comparable with the other groups, we recomputed indices for all bank groups with base as 1996 and found that new private banks perform the worst in terms of $T F P_{2}$ during the period 1996-2000.

Tables 4 to 7 also report the movement of mean $T F P_{3}$ which gives the efficiency growth component. While we have studied the behavior of cost efficiency levels of bank groups in Table $3, T F P_{3}$ represents an index based on the growth of the same efficiencies. Unlike in the levels, we find that foreign banks have mostly outperformed public and private banks in terms of efficiency growth in both models 1 and 2. However, as in the levels, public banks appear to have performed better than the private banks especially in the post-deregulation period. While new private banks are not strictly comparable with the other groups, their performance in terms of $T F P_{3}$ shows a high growth in efficiency as was evident from the efficiency levels in Figure 1. When the indices were recalculated for 1996-2000 with base at 1996, new private banks turned out to be the best performers in this period.

The composite TFP index is also reported in Tables 4 to 7 while the same is plotted in Figure 2. This gives the overall performance of banks in terms of TFP. Figure 2 clearly reveals the following salient features regarding TFP of Indian banks. First, both models 1 and 2 demonstrate that there has been a sustained rise in TFP of all bank groups during the sample period. As discussed earlier, this is an expected feature of a deregulating banking industry where improved technology as well as increased competitive pressure would lead to an inwards shift of the cost frontier, thus leading to improvement in TFP. Second, there is not much difference between public and private banks in Model 1. The rise in TFP of both the groups and in tandem with each other suggest that the ownership effect is not very strong. This points towards the fact that competitive pressure prevailed on public banks 
to maintain their productivity levels at par with that of private banks indicating that the role of competition is important in determining performance. However in Model 2, private banks exhibit a higher TFP than public banks possibly because of their better performance in technological improvement within their own environmental conditions.

(Figure 2 here)

Third, foreign banks have been the worst performers especially in the post-deregulation period which can be explained in terms of the fact that foreign banks incur a lot of expenses in acquiring top-end customers and new technology and also the pressure on foreign banks to contain costs is less as compared to other bank groups. Thus their high cost practices adversely affected their productivity. Deposits, which are considered as output in our study, form a very small fraction of foreign bank's total liabilities (59.5\% in 2000) as compared with domestic banks (over $80 \%$ in all cases). This may show up as low productivity. In fact, foreign banks do not understand local markets as well as the domestic banks do, which impairs their productivity. Small and medium entrepreneurs and often even Indian corporate entities are loathe to approaching foreign banks since they are given more flexibilities by domestic banks and also feel more comfortable in banking with the domestic banks.

Lastly, new private banks exhibited a rapid rise in TFP in both models. In fact, with indices for all banks recomputed with base as 1996, new private banks turned out to be the best performers during this period. Their TFP was the highest and increased rapidly in comparison with the other groups. The reason may be that, being late entrants, the new private banks had the advantage of not carrying any baggage from the past. Moreover these banks had to incur initial setup costs without any immediate output at the time of starting their operations. However the initial investments started yielding rapid output growth in the subsequent years. This may get manifested in the high TFP of this bank group.

\section{Conclusion}

This paper studied efficiency and productivity of scheduled commercial banks in India during the period 1986 to 2000 using a stochastic cost frontier approach. SFA gave us estimates of cost inefficiency and its determinants. Then, using the parameter and efficiency estimates from the frontiers, various measures of productivity and their components were computed. Implications were drawn in terms of the role of ownership, competition and deregulation. 
The findings of the paper may be summarized as follows. The results indicate that although there are cost inefficiencies in the Indian banking sector, they have been declining over time even while deregulation led to a slowdown in the rate of decline. In line with the cost efficiency results, we find that TFP has also gone up for all bank groups during the period under study. Thus deregulation in Indian banking industry achieved the aim of reduction in intermediation costs and improving productivity.

Interestingly, public banks have done as well as private banks (and often better) in the post-deregulation period both in terms of cost efficiency as well as TFP. This is similar to the findings of Bhaumik and Dimova (2004) who, on the basis of profit measures, concluded that public banks have been able to bridge the difference with private banks and hence the role of competition is more important than that of ownership. Similarly, using our cost measures we observe that so far as the domestic banks are concerned, the role of ownership was not as important during the phase of deregulation. Deregulation, through introduction of greater competition into the banking industry, has helped public banks to enhance their performance as indicated by their cost efficiency and TFP.

Nevertheless, foreign banks have been poor performers in terms of cost efficiency and productivity. This could be due to the costly practices followed by foreign banks in India. Moreover, deposits being a small proportion of their total liabilities may lead to the low TFP. On the other hand, performance of new private banks in terms of cost efficiency and TFP appears to have been the best in the industry. This is not a surprising result, since new private banks being recent entrants in the industry did not suffer from the burden of old costs incurred due to various factors like loss making branches, over-staffing etc., as was the case with the incumbents. As a result, while they could compete with the other groups in terms of banking services, they could also manage to keep operating costs under control.

In sum, one lesson that emerges from the empirical exercises is that intermediation costs have declined in Indian banking and total factor productivity has increased. In other words, deregulation has achieved the desired results. This is true even for public banks who appear to have benefited from the increased competition resulting from entry, and performed as well as private banks and sometimes better. More significantly, public banks have performed considerably better than foreign banks. However this result is not sufficient to say that state ownership is superior to private (domestic or foreign) ownership. It may be that less costly 
practices of the public banks get reflected in lower profitability. Moreover there may be scope of improvement in the public banks themselves as compared with where they presently stand. Whether there can be strategies for public sector banks to perform even better and what role does this leave for foreign banks to play in India is left for our future research. 


\section{References:}

1. Aigner, Dennis J., Lovell, C. A. Knox and Schmidt, Peter (1977): "Formulation and Estimation of Stochastic Frontier Production Function Models." Journal of Econometrics. 6(1): 21-37.

2. Alam, Ila M. Semenick (2001): "A Non-Parametric Approach For Assessing Productivity Dynamics Of Large Banks." Journal of Money, Credit, and Banking. 33: 121-139.

3. Barajas, Adolfo, Steiner, Roberto and Salazar, Natalia (2000): "Foreign Investment in Colombia's Financial Sector. In Claessens, S. and Marion Jansen, Eds., The Internationalization of Financial Services: Issues and Lessons for Developing Countries. Boston, Ma.: Kluwer Academic Press.

4. Battese, George E. and Coelli, Tim J. (1993): "A Stochastic Frontier Production Function Incorporating a Model for Technical Inefficiency Effects." Working Paper in Econometrics and Applied Statistics, Department of Econometrics, University of New England, Armidale, 69 .

5. Battese, George E. and Coelli, Tim J. (1995): “A Model for Technical Inefficiency Effects in a Stochastic Frontier Production Function for Panel Data." Empirical Economics. 20(2): 325-332.

6. Battese, George E. and Corra, Greg S. (1977): "Estimation of a Production Frontier Model: With Application to the Pastoral Zone of Eastern Australia." Australian Journal of Agricultural Economics. 21(3): 169-179.

7. Berger, Allen N. and Humphrey, David B. (1992): "Measurement and Efficiency Issues in Commercial Banking." In Output Measurement in the Service Sectors, edited by Z. Griliches, Chicago and London: University of Chicago Press.

8. Berger, Allen N., Leusner, John H. and Mingo, John J. (1997): "The Efficiency of Bank Branches." Journal of Monetary Economics 40(1): 141-162.

9. Berger, Allen N. and Mester, Loretta J. (1997): "Inside the Black Box: What Explains Differences in the Efficiencies of Financial Institutions?." Journal of Banking and Finance 21: 895-947. 
10. Berger, Allen N. and Mester, Loretta J. (2003): "Explaining the Dramatic Changes in Performance of US Banks: Technological Change, Deregulation, and Dynamic Changes in Competition." Journal of Financial Intermediation 12: 57-95.

11. Bhaumik, Sumon Kumar and Dimova, Ralitza (2004): "How Important is Ownership in a Market with Level Playing Field? The Indian Banking Sector Revisited." Journal of Comparative Economics 32(1): 165-180.

12. Caudill, Steven B., Ford, Jon M. and Gropper, Daniel M. (1995): "Frontier Estimation and Firm-Specific Inefficiency Measures in the Presence of Heteroscedasticity." Journal of Business and Economic Statistics 13(1):105-111.

13. Cebenoyan, A. Sinan and Cooperman, Elizabeth S. and Register, Charles A. (2000): "Managerial Stock Ownership As A Corporate Control Device: When Is Enough, Enough?", New York University Working Paper.

14. Chaffai, Mohamed E. (1997): "Estimating Input-specific Technical Inefficiency: The Case of the Tunisian Banking Industry." European Journal of Operational Research 98(2): 314-331.

15. Christopoulos, Dimitris K., Lolos, Sarantis E. G. and Tsionas, Efthymios G. (2002): "Efficiency of the Greek Banking System in View of the EMU: A Heteroscedastic Stochastic Frontier Approach." Journal of Policy Modeling 24(9): 813-829.

16. Christopoulos, Dimitris K. and Tsionas, Efthymios G. (2001): "Banking Economic Efficiency in the Deregulation Period: Results from Heteroscedastic Stochastic Frontier Models." Manchester School 69(6): 656-76.

17. Claessens, Stijn, Demirg-Kunt, Asli and Huizinga, Harry. (2000): "The Role of Foreign Banks in Domestic Banking Systems. In Stijn Claessens and Marion Jansen, Eds., The Internationalization of Financial Services: Issues and Lessons for Developing Countries. Boston, Mass.: Kluwer Academic Press.

18. Coelli, Tim J. and Battese, George E. (1996): "Identification of Factors Which Influence the Technical Inefficiency of Indian Farmers." Australian Journal of Agricultural Economics. 40(2): 103-128. 
19. Crystal, Jennifer B., Dages, Gerard and Goldberg, Linda (2001): "Does Foreign Ownership Contribute to Sounder Banks in Emerging Markets? The Latin American Experience." Federal Reserve Bank of New York Staff Reports no. $13 \%$.

20. Das, Abhiman (1997): "Technical, Allocative and Scale Efficiency of Public Sector Banks in India." Reserve Bank of India Occasional Papers 18(2,3): 279-297.

21. Grifell-Tatje, Emili and Lovell, C. A. Knox (1996): "Deregulation and Productivity Decline: The Case of Spanish Savings Banks." European Economic Review 40: 12811303.

22. Hadri, Kaddour (1999): "Estimation of a Doubly Heteroscedastic Stochastic Frontier Cost Function." Journal of Business and Economic Statistics 17(3): 359-363.

23. Hasan, Iftekhar and Hunter, William Curt (1996): "Efficiency of Japanese Multinational Banks in the United States. In Andrew H. Chen, Ed., Research in Finance, Volume 14. Greenwich, CT and London: JAI Press.

24. Hasan, Iftekhar and Lozano-Vivas, Ana (1998): "Foreign Banks, Production Technology, and Efficiency: Spanish Experience. Paper presented at Georgia Productivity Workshop III. Athens, Georgia. Processed.

25. Huang, Cliff J. and Liu Jin-Tan (1994): "Estimation of non-neutral stochastic frontier production function." Journal of Productivity Analysis 5: 171-180.

26. Indian Banks' Association.Performance Highlights of Banks. Various Issues.

27. Indian Banks' Association. Financial Analysis of Banks. Various Issues.

28. Kodde, David A. and Palm, Franz C. (1986): "Wald Criteria for Jointly Testing Equality and Inequality Restrictions." Econometrica 54(5): 1243-1248.

29. Kumbhakar, Subal C and Lovell, C. A. Knox (2000): Stochastic Frontier Analysis. Cambridge, New York and Melbourne: Cambridge University Press.

30. Kumbhakar, Subal C. and Sarkar, Sarkar (2003a): "Deregulation, Ownership, and Productivity Growth: Evidence from Indian Banks." Journal of Money, Credit, and Banking 35(3): 403-424. 
31. Kumbhakar, S. C. and Sarkar, Subrata (2003b): "Deregulation, Ownership and Efficiency Change in Indian Banking: An Application of Stochastic Frontier Analysis." Arthaniti 2(1-2): 1-26.

32. Meeusen, Wim, and van den Broeck, Julien (1977): "Efficiency Estimation From Cobb Douglas Production Function With Composed Error." International Economic Review 18(2): 435-444.

33. Reserve Bank of India (2002): "Expenditure Pattern and IT Initiatives of Banks." Monthly Bulletin December: 849-867.

34. Reserve Bank of India (2005): Handbook of Statistics on Indian Economy.

35. Sarkar, Jayati, Sarkar, Subrata, and Bhaumik, Sumon Kumar (1998): "Does Ownership Always Matter? Evidence from the Indian Banking Industry." Journal of Comparative Economics 26(2): 262-281.

36. Shanmugam, Kumarapalayam R. and Das, Abhiman (2004): "Efficiency of Indian Commercial Banks During the Reform Period." Applied Financial Economics 14(9): 681-686.

37. Vennet, Rudi Vander (1996): "The Effect of Mergers and Acquisitions on the Efficiency and Profitability of EC Credit Institutions. Journal of Banking and Finance 20(9): 1531-1558.

38. Wang, Hung-Jen (2003): "A Stochastic Frontier Analysis of Financing Constraints on Investment: The Case of Financial Liberalization in Taiwan." Journal of Business and Economic Statistics 21(3): 406-419.

39. Yildirim, H. Semih and Philippatos, George C. (2002): "Efficiency of Banks: Recent Evidence from the Transition Economies of Europe: 1993-2000." University of Saskatchewan Working Paper. 
Table 1: Maximum Likeli-hood Estimates of the Stochastic Cost Frontier Without Group Dummies based on Panel Data for Banks for Years 1986 to 2000

\begin{tabular}{|c|c|c|c|c|c|}
\hline Beta & Estimate & t-ratio & Delta & Estimate & t-ratio \\
\hline CONST & -2.967 & -3.450 & CONST & -3.044 & -3.868 \\
\hline FD & 2.002 & 3.803 & $\mathrm{~T}$ & -0.050 & -0.600 \\
\hline SD & -1.135 & -4.806 & DER & -0.516 & -0.636 \\
\hline CD & -0.413 & -1.754 & SIZE & -1.197 & -3.948 \\
\hline INV & -0.804 & -2.130 & PUB & -15.421 & -11.846 \\
\hline ADV & -0.087 & -0.213 & PVT & 0.220 & 0.279 \\
\hline B & 1.688 & 11.281 & NPVT & 1.547 & 1.925 \\
\hline W & 0.235 & 1.653 & $\mathrm{DER}^{*} \mathrm{~T}$ & 0.128 & 0.953 \\
\hline $\mathrm{T}$ & 0.126 & 3.423 & $\mathrm{DER}^{*} \mathrm{PUB}$ & 0.133 & 0.178 \\
\hline $\mathrm{FD}^{2}$ & -0.023 & -0.238 & $\mathrm{DER}^{*} \mathrm{PVT}$ & 0.586 & 0.808 \\
\hline $\mathrm{SD}^{2}$ & -0.120 & -2.985 & DER*NPVT & 3.094 & 1.925 \\
\hline $\mathrm{CD}^{2}$ & -0.044 & -0.977 & $\mathrm{~T}^{2}$ & 0.003 & 0.372 \\
\hline INV $^{2}$ & 0.024 & 0.138 & $\mathrm{SIZE}^{2}$ & -0.260 & -2.627 \\
\hline $\mathrm{ADV}^{2}$ & 0.264 & 2.355 & $\mathrm{~T}^{*} \mathrm{SIZE}$ & -0.011 & -0.301 \\
\hline $\mathrm{B}^{2}$ & -0.016 & -0.775 & $\mathrm{~T}^{*} \mathrm{PUB}$ & 0.220 & 2.764 \\
\hline$W^{2}$ & -0.007 & -0.491 & $\mathrm{~T}^{*} \mathrm{PVT}$ & 0.069 & 0.921 \\
\hline $\mathrm{T}^{2}$ & -0.004 & -3.472 & T*NPVT & -0.593 & -5.421 \\
\hline $\mathrm{FD}^{*} \mathrm{SD}$ & 0.240 & 3.175 & SIZE*DER & 0.077 & 0.237 \\
\hline $\mathrm{FD}^{*} \mathrm{CD}$ & 0.082 & 1.122 & SIZE*PUB & -4.342 & -11.892 \\
\hline FD*INV & 0.027 & 0.194 & $\mathrm{SIZE}^{*} \mathrm{PVT}$ & -0.064 & -0.168 \\
\hline $\mathrm{FD}^{*} \mathrm{ADV}$ & -0.288 & -3.383 & SIZE*NPVT & 0.144 & 0.500 \\
\hline $\mathrm{FD}^{*} \mathrm{~B}$ & -0.123 & -2.772 & $\mathrm{~L}$ & 3.563 & 5.579 \\
\hline $\mathrm{FD}^{*} \mathrm{~W}$ & 0.076 & 1.571 & K & 12.451 & 11.054 \\
\hline $\mathrm{FD}^{*} \mathrm{~T}$ & -0.022 & -1.846 & $\mathrm{~L}^{2}$ & -1.521 & -4.817 \\
\hline $\mathrm{SD}^{*} \mathrm{CD}$ & 0.012 & 0.417 & $K^{2}$ & 1.134 & 0.697 \\
\hline SD*INV & -0.167 & -2.660 & $\mathrm{~L}^{* \mathrm{~T}}$ & -0.006 & -0.085 \\
\hline $\mathrm{SD} * \mathrm{ADV}$ & -0.066 & -1.314 & $\mathrm{~L}^{*} \mathrm{SIZE}$ & 1.122 & 3.329 \\
\hline $\mathrm{SD}^{*} \mathrm{~B}$ & 0.083 & 3.231 & L*DER & 0.053 & 0.082 \\
\hline $\mathrm{SD}^{*} \mathrm{~W}$ & -0.077 & -3.934 & $\mathrm{~L}^{*} \mathrm{PUB}$ & 10.442 & 12.679 \\
\hline $\mathrm{SD}^{*} \mathrm{~T}$ & 0.014 & 2.257 & $\mathrm{~L} * \mathrm{PVT}$ & -1.612 & -2.557 \\
\hline CD*INV & -0.058 & -0.901 & L*NPVT & -0.060 & -0.088 \\
\hline $\mathrm{CD}^{*} \mathrm{ADV}$ & -0.022 & -0.380 & $\mathrm{~L}^{*} \mathrm{~K}$ & -6.797 & -6.281 \\
\hline $\mathrm{CD}^{*} \mathrm{~B}$ & 0.023 & 1.134 & $\mathrm{~K}^{*} \mathrm{~T}$ & -0.238 & -1.782 \\
\hline $\mathrm{CD}^{*} \mathrm{~W}$ & -0.030 & -1.331 & $\mathrm{~K}^{*} \mathrm{SIZE}$ & 1.479 & 2.107 \\
\hline $\mathrm{CD}^{* \mathrm{~T}}$ & 0.010 & 1.954 & $\mathrm{~K}^{*} \mathrm{DER}$ & -3.086 & -2.165 \\
\hline INV*ADV & 0.170 & 2.090 & $\mathrm{~K}^{*} \mathrm{PUB}$ & 5.732 & 5.206 \\
\hline $\mathrm{INV}^{*} \mathrm{~B}$ & 0.058 & 1.518 & $\mathrm{~K} * \mathrm{PVT}$ & 5.887 & 4.475 \\
\hline $\mathrm{INV}^{*} \mathrm{~W}$ & -0.018 & -0.487 & $\mathrm{~K}^{*} \mathrm{NPVT}$ & -0.020 & -0.017 \\
\hline $\mathrm{INV}^{*} \mathrm{~T}$ & 0.015 & 1.302 & Sigma $^{2}$ & 0.057 & 22.958 \\
\hline $\mathrm{ADV}^{*} \mathrm{~B}$ & -0.014 & -0.462 & Gamma & 0.832 & 59.891 \\
\hline $\mathrm{ADV}^{*} \mathrm{~W}$ & -0.026 & -0.683 & Log Likelihood & 561.475 & \\
\hline $\mathrm{ADV}^{*} \mathrm{~T}$ & -0.005 & -0.509 & LR Test for $\gamma=\delta_{i}=0, \forall i$ & $692.286^{*}$ & \\
\hline $\mathrm{B} * \mathrm{~W}$ & 0.104 & 8.387 & LR Test for $\delta_{i}=0, \forall i$ & $690.666^{*}$ & \\
\hline $\mathrm{B}^{*} \mathrm{~T}$ & -0.011 & -3.148 & Number of Banks & 83 & \\
\hline $\mathrm{W}^{*} \mathrm{~T}$ & 0.005 & 1.359 & Number of Observations & 991 & \\
\hline
\end{tabular}

Notes: FD = Fixed Deposits, SD = Saving Deposits, CD = Current Deposits

$\mathrm{INV}=$ Investments, ADV $=$ Loans and Advances, $\mathrm{B}=$ Number of branches,

$\mathrm{W}=$ Wage-rental ratio, $\mathrm{T}=$ Time trend (Year), ${ }^{*}$ denotes significance (Kodde and Palm, 1986) 
Table 2: Maximum Likeli-hood Estimates of the Stochastic Cost Frontier With Group Dummies based on Panel Data for Banks for Years 1986 to 2000

\begin{tabular}{|c|c|c|c|c|c|}
\hline Beta & Estimate & t-ratio & Delta & Estimate & t-ratio \\
\hline CONST & -3.547 & -3.934 & CONST & -1.847 & -2.712 \\
\hline FD & 1.339 & 2.816 & $\mathrm{~T}$ & 0.030 & 0.406 \\
\hline SD & -1.133 & -5.153 & DER & -0.653 & -1.091 \\
\hline $\mathrm{CD}$ & -0.090 & -0.395 & SIZE & -0.810 & -3.198 \\
\hline INV & -0.351 & -1.032 & PUB & -11.322 & -11.213 \\
\hline ADV & -0.140 & -0.358 & PVT & -4.022 & -8.643 \\
\hline B & 1.176 & 7.712 & NPVT & 1.316 & 1.710 \\
\hline $\mathrm{W}$ & 0.054 & 0.392 & $\mathrm{DER}^{*} \mathrm{~T}$ & 0.057 & 0.690 \\
\hline $\mathrm{T}$ & 0.192 & 4.806 & DER*PUB & -0.098 & -0.157 \\
\hline $\mathrm{FD}^{2}$ & 0.014 & 0.158 & DER*PVT & -0.500 & -0.887 \\
\hline $\mathrm{SD}^{2}$ & -0.100 & -2.941 & DER*NPVT & 2.632 & 1.710 \\
\hline $\mathrm{CD}^{2}$ & 0.005 & 0.128 & $\mathrm{~T}^{2}$ & 0.004 & 0.723 \\
\hline INV $^{2}$ & -0.147 & -0.987 & $\mathrm{SIZE}^{2}$ & -0.192 & -2.415 \\
\hline $\mathrm{ADV}^{2}$ & 0.179 & 1.722 & $\mathrm{~T}^{*} \mathrm{SIZE}$ & 0.005 & 0.196 \\
\hline $\mathrm{B}^{2}$ & 0.038 & 1.863 & T*PUB & 0.300 & 4.352 \\
\hline $\mathrm{W}^{2}$ & -0.027 & -1.960 & T*PVT & 0.210 & 3.415 \\
\hline $\mathrm{T}^{2}$ & -0.006 & -4.779 & $\mathrm{~T}^{*} \mathrm{NPVT}$ & -0.213 & -2.365 \\
\hline $\mathrm{FD}^{*} \mathrm{SD}$ & 0.126 & 2.051 & SIZE*DER & -0.112 & -0.527 \\
\hline $\mathrm{FD}^{*} \mathrm{CD}$ & 0.008 & 0.123 & SIZE*PUB & -3.476 & -12.736 \\
\hline FD*INV & 0.090 & 0.750 & SIZE*PVT & -1.340 & -4.665 \\
\hline $\mathrm{FD}^{*} \mathrm{ADV}$ & -0.249 & -3.245 & SIZE*NPVT & 0.415 & 1.835 \\
\hline $\mathrm{FD}^{*} \mathrm{~B}$ & -0.066 & -1.869 & $\mathrm{~L}$ & 2.176 & 4.052 \\
\hline $\mathrm{FD}^{*} \mathrm{~W}$ & 0.047 & 1.075 & K & 11.306 & 10.598 \\
\hline $\mathrm{FD}^{* \mathrm{~T}}$ & -0.021 & -1.898 & $\mathrm{~L}^{2}$ & -0.656 & -2.529 \\
\hline $\mathrm{SD} * \mathrm{CD}$ & 0.008 & 0.316 & $\mathrm{~K}^{2}$ & 0.855 & 0.703 \\
\hline SD*INV & -0.037 & -0.715 & $\mathrm{~L}^{*} \mathrm{~T}$ & -0.084 & -1.344 \\
\hline SD*ADV & -0.026 & -0.590 & L*SIZE & 0.770 & 2.801 \\
\hline $\mathrm{SD} * \mathrm{~B}$ & 0.042 & 1.862 & L*DER & 0.491 & 0.935 \\
\hline $\mathrm{SD} * \mathrm{~W}$ & -0.084 & -4.743 & L*PUB & 6.804 & 10.613 \\
\hline $\mathrm{SD}^{* \mathrm{~T}}$ & 0.016 & 2.812 & L*PVT & 1.764 & 4.218 \\
\hline CD*INV & -0.028 & -0.499 & L*NPVT & -0.645 & -1.270 \\
\hline $\mathrm{CD}^{*} \mathrm{ADV}$ & -0.004 & -0.083 & $\mathrm{~L} * \mathrm{~K}$ & -5.780 & -5.947 \\
\hline $\mathrm{CD} * \mathrm{~B}$ & 0.007 & 0.416 & $\mathrm{~K}^{* \mathrm{~T}}$ & -0.150 & -1.566 \\
\hline $\mathrm{CD} * \mathrm{~W}$ & -0.006 & -0.284 & $\mathrm{~K}^{*} \mathrm{SIZE}$ & 1.037 & 2.111 \\
\hline $\mathrm{CD}^{*} \mathrm{~T}$ & 0.011 & 2.045 & $\mathrm{~K}^{*} \mathrm{DER}$ & -2.608 & -2.902 \\
\hline INV*ADV & 0.092 & 1.234 & K*PUB & 3.676 & 3.622 \\
\hline $\mathrm{INV}^{*} \mathrm{~B}$ & 0.039 & 1.188 & $\mathrm{~K}^{*} \mathrm{PVT}$ & 2.249 & 2.240 \\
\hline $\mathrm{INV}^{*} \mathrm{~W}$ & 0.000 & 0.006 & $\mathrm{~K}^{*} \mathrm{NPVT}$ & -2.277 & -2.658 \\
\hline $\mathrm{INV}^{*} \mathrm{~T}$ & 0.018 & 1.697 & Sigma $^{2}$ & 0.032 & 13.093 \\
\hline $\mathrm{ADV} * \mathrm{~B}$ & 0.021 & 0.801 & Gamma & 0.839 & 53.782 \\
\hline $\mathrm{ADV}^{*} \mathrm{~W}$ & -0.033 & -0.924 & Log Likelihood & 650.190 & \\
\hline $\mathrm{ADV}^{*} \mathrm{~T}$ & 0.001 & 0.154 & LR Test for $\gamma=\delta_{i}=0, \forall i$ & $711.174^{*}$ & \\
\hline B*W & 0.105 & 9.240 & LR Test for $\delta_{i}=0, \forall i$ & $692.902 *$ & \\
\hline $\mathrm{B}^{*} \mathrm{~T}$ & -0.019 & -4.921 & Number of Banks & 83 & \\
\hline $\mathrm{W}^{*} \mathrm{~T}$ & 0.009 & 2.630 & Number of Observations & 991 & \\
\hline PUB & 1.738 & 11.654 & & & \\
\hline PVT & 1.460 & 9.381 & & & \\
\hline NEWPVT & -0.803 & -3.431 & & & \\
\hline
\end{tabular}


Table 3: Mean Cost Efficiency of Bank Groups

(Figures in percentage)

\begin{tabular}{|c|r|r|r|r|r|r|r|r|}
\hline & \multicolumn{2}{|c|}{ Mean Cost Efficiency Without Group Dummies } & \multicolumn{3}{|c|}{ Mean Cost Efficiency With Group Dummies } \\
\hline Year & Public & Private & Foreign & New Private & Public & Private & Foreign & New Private \\
\hline 1986 & 87.40 & 96.58 & 34.52 &. & 85.35 & 82.95 & 18.63 &. \\
1987 & 88.85 & 96.57 & 34.71 &. & 87.67 & 82.76 & 18.70 &. \\
1988 & 88.98 & 96.28 & 32.27 &. & 88.45 & 81.76 & 17.20 & \\
1989 & 92.83 & 96.38 & 41.41 &. & 93.09 & 83.24 & 21.36 &. \\
1990 & 94.16 & 96.57 & 44.37 &. & 94.64 & 81.83 & 25.00 &. \\
1991 & 94.16 & 96.47 & 45.67 &. & 94.66 & 80.58 & 24.98 &. \\
1992 & 92.17 & 96.51 & 47.80 &. & 92.38 & 80.06 & 25.77 &. \\
1993 & 91.45 & 95.39 & 38.31 &. & 90.97 & 81.51 & 20.64 &. \\
1994 & 88.51 & 94.08 & 49.86 &. & 86.65 & 79.86 & 34.20 &. \\
1995 & 89.86 & 93.36 & 51.43 &. & 88.72 & 80.52 & 35.68 &. \\
1996 & 90.47 & 92.17 & 47.77 & 42.09 & 89.52 & 76.53 & 31.64 &. \\
1997 & 90.88 & 88.98 & 47.25 & 55.71 & 90.18 & 74.00 & 31.38 & 9.04 \\
1998 & 91.94 & 88.27 & 45.98 & 64.90 & 91.46 & 74.51 & 30.61 & 10.40 \\
1999 & 92.29 & 88.79 & 45.24 & 71.35 & 91.89 & 74.04 & 29.67 & 10.11 \\
2000 & 93.97 & 88.30 & 48.21 & 80.28 & 93.89 & 78.76 & 30.81 & 10.35 \\
\hline
\end{tabular}

Note: . for new private banks prior to their entry. 
Table 4: Indices of Total Factor Productivity and its Components Without Group Dummies

(Figures in percentage)

\begin{tabular}{|r|r|r|r|r|r|r|r|r|r|r|r|r|}
\hline & \multicolumn{2}{|c|}{ Technical Change Component } & \multicolumn{2}{|c|}{ Scale Effects Component } & \multicolumn{2}{|c|}{ Efficiency Component } & \multicolumn{2}{|c|}{ Total Factor Productivity } \\
\hline Year & Public & Private & Foreign & Public & Private & Foreign & Public & Private & Foreign & Public & Private & Foreign \\
\hline 1986 & 100.00 & 100.00 & 100.00 & 100.00 & 100.00 & 100.00 & 100.00 & 100.00 & 100.00 & 100.00 & 100.00 & 100.00 \\
1987 & 99.75 & 100.90 & 97.54 & 100.00 & 99.92 & 99.79 & 101.63 & 99.99 & 104.68 & 101.38 & 100.81 & 102.01 \\
1988 & 99.78 & 102.24 & 95.89 & 100.09 & 100.14 & 99.95 & 101.67 & 99.77 & 96.00 & 101.54 & 102.15 & 91.98 \\
1989 & 100.23 & 104.11 & 94.68 & 99.96 & 100.00 & 99.72 & 106.14 & 99.88 & 116.69 & 106.34 & 103.99 & 110.44 \\
1990 & 101.10 & 106.20 & 94.04 & 99.90 & 99.87 & 100.64 & 107.75 & 100.07 & 125.38 & 108.81 & 106.13 & 118.95 \\
1991 & 102.30 & 108.68 & 93.91 & 99.92 & 99.79 & 100.39 & 107.75 & 99.96 & 129.64 & 110.11 & 108.41 & 122.51 \\
1992 & 104.05 & 111.37 & 92.59 & 99.98 & 99.72 & 100.05 & 105.36 & 100.01 & 142.85 & 109.62 & 111.07 & 132.86 \\
1993 & 106.20 & 114.94 & 91.84 & 100.05 & 99.49 & 99.18 & 104.55 & 98.82 & 106.64 & 111.13 & 113.06 & 96.95 \\
1994 & 108.41 & 118.80 & 92.52 & 100.02 & 99.25 & 100.01 & 101.01 & 97.28 & 124.41 & 109.63 & 114.81 & 114.65 \\
1995 & 110.81 & 122.95 & 93.82 & 99.90 & 98.82 & 101.08 & 102.62 & 96.56 & 120.26 & 113.68 & 117.48 & 113.65 \\
1996 & 113.80 & 128.01 & 96.08 & 99.77 & 98.60 & 100.10 & 103.34 & 95.42 & 110.98 & 117.39 & 120.67 & 106.53 \\
1997 & 117.09 & 133.86 & 98.21 & 99.63 & 97.73 & 97.66 & 103.83 & 93.98 & 105.93 & 121.19 & 124.09 & 101.43 \\
1998 & 120.91 & 140.69 & 100.78 & 99.45 & 97.40 & 97.99 & 105.06 & 93.60 & 105.45 & 126.35 & 129.50 & 103.97 \\
1999 & 125.27 & 148.05 & 103.76 & 99.27 & 97.06 & 98.17 & 105.44 & 94.28 & 104.03 & 131.15 & 136.76 & 105.84 \\
2000 & 130.17 & 155.84 & 106.66 & 99.02 & 97.68 & 98.50 & 107.42 & 94.33 & 109.12 & 138.40 & 144.90 & 114.32 \\
\hline
\end{tabular}

Table 5: Indices of Total Factor Productivity and its Components for New Private Banks Without Group Dummies

(Figures in percentage)

\begin{tabular}{|r|r|r|r|r|}
\hline Year & Technical Change Component & Scale Effects Component & Efficiency Component & Total Factor Productivity \\
\hline 1995 & 100.00 & 100.00 & 100.00 & 100.00 \\
1996 & 104.40 & 95.76 & 126.12 & 126.06 \\
1997 & 108.76 & 92.10 & 149.00 & 149.39 \\
1998 & 112.50 & 90.43 & 157.16 & 159.99 \\
1999 & 116.59 & 87.95 & 187.49 & 192.30 \\
\hline
\end{tabular}


Table 6: Indices of Total Factor Productivity and its Components With Group Dummies

(Figures in percentage)

\begin{tabular}{|c|r|r|r|r|r|r|r|r|r|r|r|r|}
\hline & \multicolumn{2}{|c|}{ Technical Change Component } & \multicolumn{2}{c|}{ Scale Effects Component } & \multicolumn{2}{c|}{ Efficiency Component } & \multicolumn{2}{|c|}{ Total Factor Productivity } \\
\hline Year & Public & Private & Foreign & Public & Private & Foreign & Public & Private & Foreign & Public & Private & Foreign \\
\hline 1986 & 100.00 & 100.00 & 100.00 & 100.00 & 100.00 & 100.00 & 100.00 & 100.00 & 100.00 & 100.00 & 100.00 & 100.00 \\
1987 & 98.94 & 102.31 & 96.10 & 100.39 & 100.68 & 108.09 & 102.72 & 99.77 & 104.20 & 102.05 & 102.76 & 108.40 \\
1988 & 98.35 & 105.37 & 93.38 & 100.74 & 100.22 & 110.50 & 103.48 & 98.42 & 94.72 & 102.56 & 103.97 & 97.87 \\
1989 & 98.23 & 109.17 & 90.93 & 101.22 & 100.99 & 123.04 & 109.07 & 100.24 & 112.47 & 108.46 & 110.44 & 124.75 \\
1990 & 98.69 & 113.41 & 89.09 & 101.56 & 101.31 & 115.37 & 110.97 & 98.51 & 130.43 & 111.22 & 113.18 & 134.37 \\
1991 & 99.65 & 118.38 & 87.69 & 101.66 & 101.63 & 122.68 & 110.98 & 96.86 & 131.94 & 112.41 & 116.59 & 142.34 \\
1992 & 101.38 & 123.82 & 84.45 & 101.61 & 102.18 & 124.15 & 108.19 & 96.54 & 144.36 & 111.49 & 122.20 & 152.19 \\
1993 & 103.60 & 130.47 & 81.82 & 101.69 & 102.98 & 131.01 & 106.49 & 98.19 & 104.43 & 112.27 & 131.81 & 113.76 \\
1994 & 106.09 & 137.69 & 81.12 & 101.92 & 103.76 & 114.28 & 101.08 & 95.88 & 130.61 & 109.52 & 137.01 & 126.78 \\
1995 & 108.78 & 145.27 & 81.18 & 102.04 & 104.61 & 113.48 & 103.57 & 96.57 & 129.01 & 115.13 & 146.66 & 124.44 \\
1996 & 112.09 & 154.11 & 82.19 & 102.01 & 105.14 & 112.91 & 104.55 & 91.86 & 113.56 & 119.68 & 149.17 & 110.45 \\
1997 & 115.91 & 164.22 & 83.12 & 102.00 & 107.66 & 120.90 & 105.37 & 90.42 & 107.29 & 124.69 & 157.85 & 113.41 \\
1998 & 120.38 & 175.88 & 84.74 & 101.94 & 108.45 & 117.25 & 106.87 & 90.94 & 108.83 & 131.19 & 171.13 & 113.84 \\
1999 & 125.60 & 188.85 & 87.06 & 101.86 & 108.99 & 116.43 & 107.35 & 90.35 & 107.94 & 137.37 & 183.48 & 115.22 \\
2000 & 131.50 & 202.59 & 89.43 & 101.70 & 106.81 & 116.19 & 109.78 & 96.10 & 112.60 & 146.72 & 204.85 & 123.09 \\
\hline
\end{tabular}

Table 7: Indices of Total Factor Productivity and its Components for New Private Banks With Group Dummies

(Figures in percentage)

\begin{tabular}{|r|r|r|r|r|}
\hline Year & Technical Change Component & Scale Effects Component & Efficiency Component & Total Factor Productivity \\
\hline 1995 & 100.00 & 100.00 & 100.00 & 100.00 \\
1996 & 104.36 & 117.32 & 107.92 & 129.30 \\
1997 & 108.81 & 133.67 & 105.06 & 149.42 \\
1998 & 112.58 & 143.74 & 102.18 & 161.75 \\
1999 & 116.73 & 156.44 & 110.40 & 195.02 \\
\hline
\end{tabular}


Figure 1: Mean Cost Efficiency
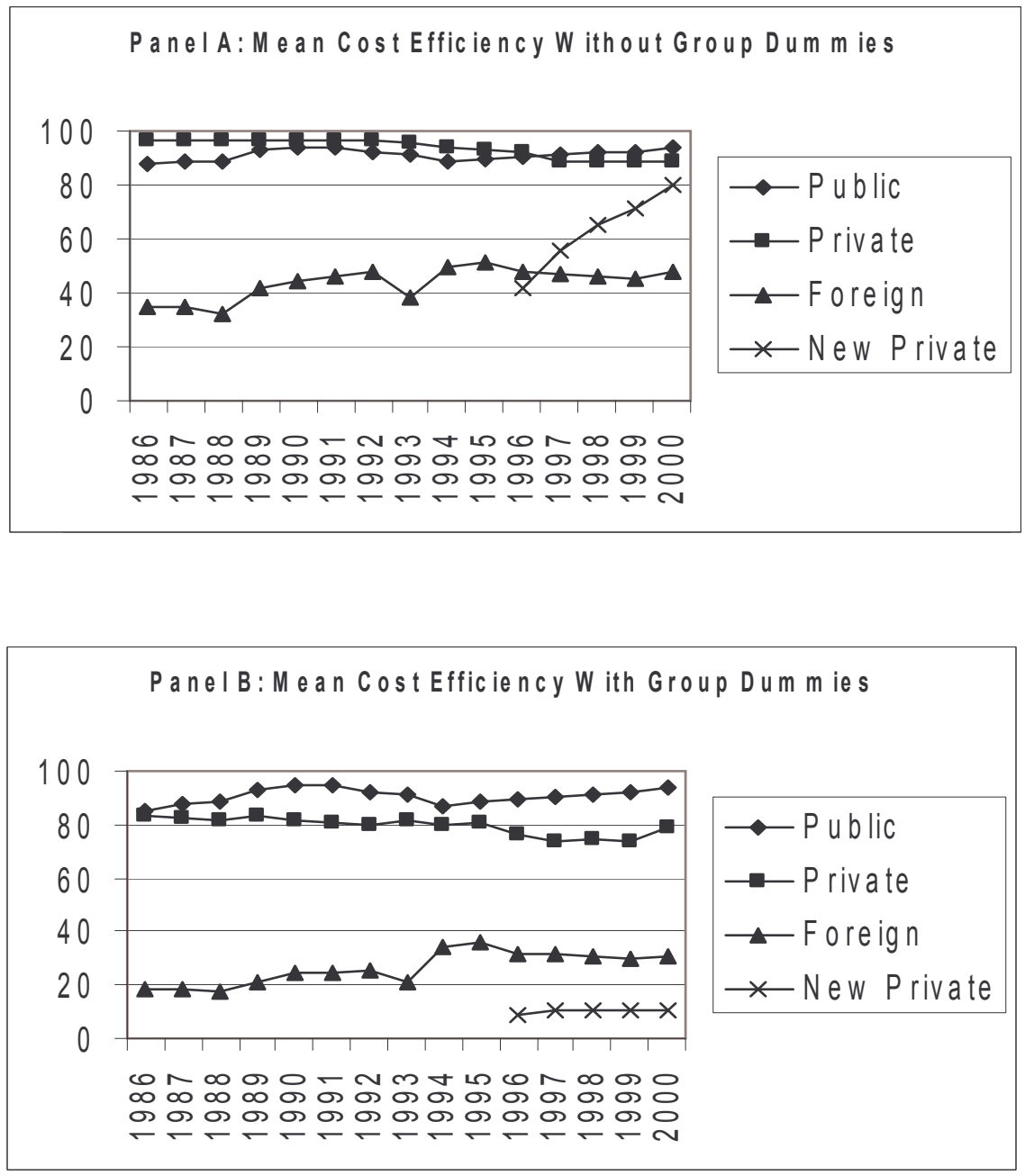
Figure 2: Indices of Total Factor Productivity
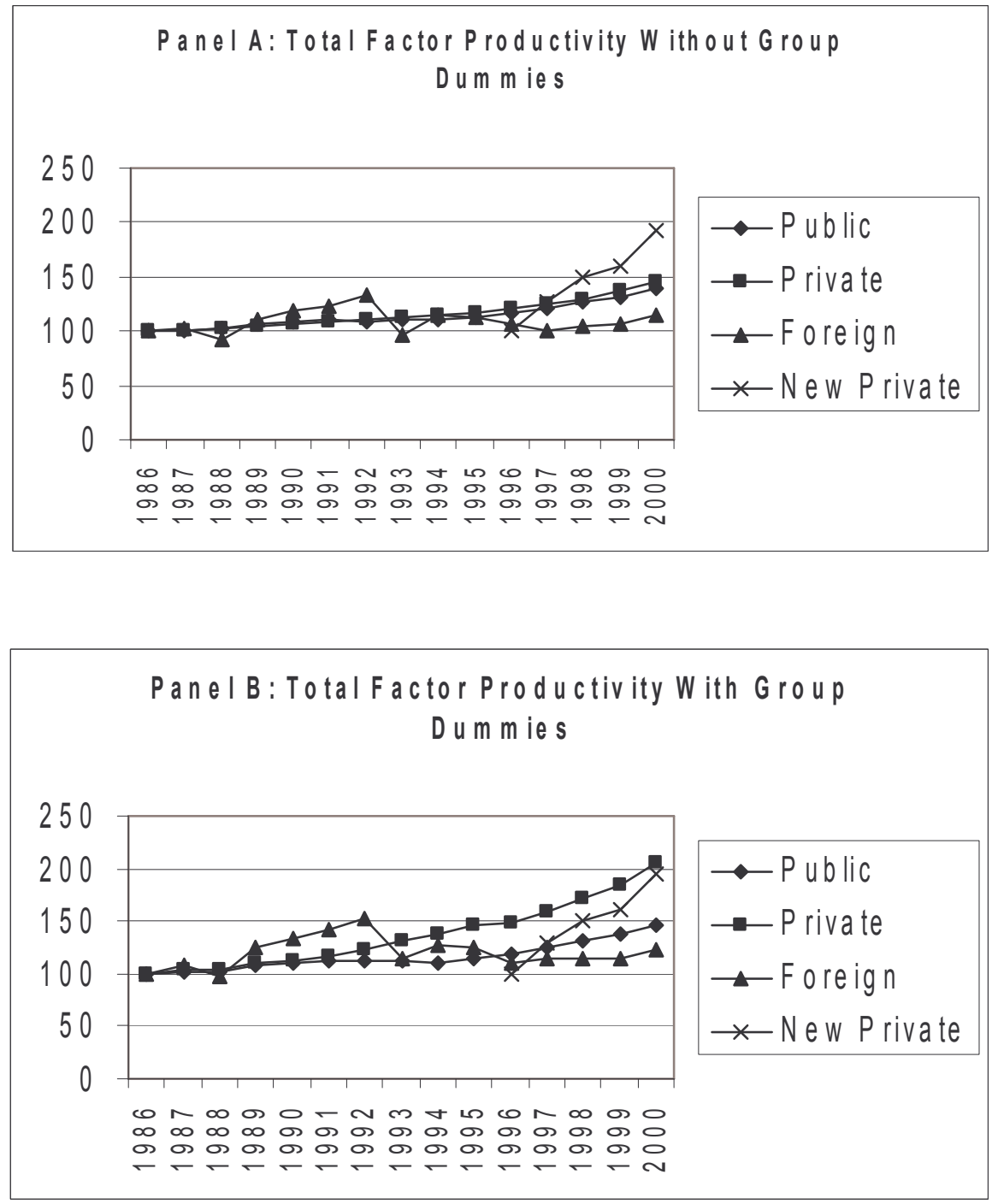